\title{
bCom ldan rig ral on the Methods for Proving Momentariness
}

\author{
CHOI Kyeongjin
}

bCom ldan Rig pa'i ral gri Dar ma rgyal mtshan (1227-1305, hereafter bCom ldan rig ral), a sNar thang-based master from the bKa' gdams school but quite familiar to masters from the Sa skya school, is a remarkable person in terms of his curriculum and political activities as well as the circumstances surrounding him (cf. van der Kuijp 2016, 262266). Also, with regard to his Buddhist epistemological understanding, his wide range of commentaries and bsdus don texts on major and minor treatises composed by several Indian Buddhist logicians (not only Dharmakirti, unlike most of bKa' gdams school's masters) reflect his deep interest in Buddhist epistemology. Apparently, due to his rich experience and understanding, he seems to have not been obedient to the ideological tradition of the bKa' gdams or Sa skya school: for example, he criticizes Sapan and bKa' gdams masters in relation to the issue of perception's objects.

Furthermore, with regard to the issue of proving momentariness in the Buddhist pramanna tradition, masters of the dGe lugs school, who are the successors to the bKa' gdams school, advocated an interpretation very similar to that of bCom ldan rig ral rather than those of rNgog or Phya pa. I cannot say if dGe lugs masters at times follow bCom ldan rig ral's thought with regard to topics other than the deduction of momentariness. While bCom ldan rig ral's influence on the history of Tibetan Buddhist epistemology is worth looking into and, in some degree, should be considered, nevertheless great logicians from the bKa' gdams school like rNgog and Phya pa have attracted the most attention over the years.

In this paper, I will first survey several interpretations provided by predecessors of and successors to bCom ldan rig ral in order to compare them with his understanding of the methods for proving momentariness. After that I will present his own statement and then point out the possibility that he served as a turning point in the 
understanding of the issue in question.

\section{Several Interpretations of the Methods of Proving Momentariness}

The argument for proving momentariness in Dharmakīti's (7c.) Pramānaviniścaya (hearafter, PVin) arises from the question "By what pramanna can one say that all produced things are definitely impermanent?" Dharmakīti presents two verification methods as possible answers:

Method [1]: All produced things are definitely impermanent because they vanish by their own nature, without depending on any other causes.

Method [2]: Permanent existence cannot exist because it lacks causal efficacy (arthakriyā). Therefore, all existent things are definitely impermanent.

Method [1] is a traditional approach from the Abhidharmakośabhāsya whereas Method [2] is seen as a pioneering view of Dharmakīti himself. Incidentally, after Buddhist philosophy was transferred to Tibet, Method [1], whose main idea is nirapekșatva (nondependence [on the outer causes]), was presented as ltos med kyi gtan tshigs in Tibetan, and Method [2], which is characterized by bādhakapramanna (pramāna that rejects), as gnod pa can gyi gtan tshigs.

Dharmottara (8c.), who wrote the very first commentary on the PVin, argues that although Method [2] is more efficient than Method [1] for demonstrating that all existent things are pervaded by impermanence, Method [1] needs to be argued because it helps Method [2] become a complete and clean demonstration (cf. Sakai 2011). And yet at the same time he also regards Method [1] as expressing neither more nore less the same as Method [2]. We need to pay attention to his former interpretation because after rNgog introduced Dharmottara's interpretations nobody in Tibet (as far as I can tell) touches on the latter one. Thus, for reader's convenience, I would like to refer to the former one as "Dharmottara's assertion" in this paper.

The reason that rNgog seems to have encouraged bKa' gdams masters to immerse themselves in investigating the PVin is that he not only translated the PVin and Dharmottara's commentary on it but also that he composed his own commentary on it. In his commentary, rNgog sums up Dharmottara's assertion and criticizes it for contradicting the PVin and being illogical (cf. Choi 2016), because rNgog understood that Method [2] is merely an extension of substantiating Method [1]'s pervasion (vyāpti) 
in order to refute non-Buddhists who claim a permanent existent. rNgog's criticism of Dharmottara's assertion and his own understanding of he two methods are reflected in his successors' commentaries on the PVin until bCom ldan rig ral's appearance.

Before inquiring into bCom ldan rig ral's thought, I would like to glance at what dGe lugs masters (after the 14th century) said regarding previous teachers' interpretation and their own explanation. There are three views on this topic (cf. Choi 2016): (a) One that follows Dharmottara's assertion; (b) One that sees Method [1] as confirming the positive concomitance and Method [2] as confirming the negative concomitance of all produced things with impermanence; (c) One that sees Method [1] as demonstrating the rang ldog of svabhāvapratibandha whereas Method [2] as demonstrating its mtshan nyid (cf. Choi 2015).

Putting aside (c), which does not directly relate to proving momentariness, the most notable view is (a). Notwithstanding rNgog's criticism of Dharmottara's assertion, dGe lugs masters, who are supposed to be following the bKa' gdams school's principles in general, advocate Dharmottara's understanding. At the same time, in the dGe lugs' understanding, Method [1] and [2] differ in how they prove the same thing (positively and negatively, respectively). Furthermore, in the above three views of the dGe lugs school, one cannot find rNgog's interpretation that I previously referred to.

I believe in the context above there was some sort of catalyst that changed the exegetical track in the 13th century, which may have been bCom ldan rig ral.

\section{2. bCom ldan rig ral in the rNam nges rGyan gyi me tog}

In the rNam nges rGyan gyi me tog, bCom ldan rig ral's commentary on the PVin, he first divides the part where Dharmakirti established that all produced/existent things are definitely impermanent into five sections as follows:

For the fifth point (i.e., Demonstration that the logical reason and the object have the same one nature), there are five sections: (i) Demonstrating by means of the ltos med kyi rtags (i.e., Method [1]), (ii) Demonstrating by means of the gnod pa can gyi rigs (i.e., Method [2]), (iii) Demonstrating the rationality in terms of the [five] aggregation[s] by means of an inference and a perception, (iv) Rejecting an accusation in relation to the ltos med kyi rtags (i.e., Method [1]), (v) Describing another way of demonstration for proving [the validity of] non-dependence [from other causes] (ltos med). (rNam nges rGyan gyi me tog, 321) 
Among these five sections, (i) and (ii) are linked to Method [1] and [2] respectively, but one can hardly grasp bCom ldan rig ral's opinion about the relationship of both methods. However, at minimum, he seems not to hierarchically place Method [2] as an ancillary part of Method [1], unlike rNgog and others.

Right after the above, bCom ldan rig ral raises a counterargument that questions the necessity of the two methods for proving the same thing. In reply, he summarizes Dharmottara's assertion, and then introduces an interpretation which is seemingly quite close to that of Sapan and Bo dong Sho re ba (13c., cf. Choi 2016), but he does not clear with whom he is in agreement.

However, bCom ldan rig ral seems to approve of Dharmottara's assertion below. In the very last line of section (ii), concluding the demonstration by Method [2], he positions Method [2] as a vehicle for proving the pervasion between all produced existing things and impermanence and Method [1] as an assistant validation to ensure Method [2]'s logical consistency.

As observed above, when the permanent is denied, [the object of the inference] turns out to be impermanent. After making the road [of Method [2]] clean by the fact that there is no cause of extinction (= Method [1]), one demonstrates the pervasion by means of the exact gnod pa can gyis [rigs] (= Method [2]). That is, this is nothing but that told [by Dharmakîrti] in the Vãdanyāya"Here, as a substantiation of the pervasion, [I (= Dharmakirti)] taught about valid cognition (tshad $\mathrm{ma}$ ) which rejects [the existence of a valid reason] on the opposite side of the inferential object." (rNam nges rGyan gyi me tog, 327)

Finally, at the end of the exposition of the demonstration of momentariness using Method [2], bCom ldan rig ral declares an interpretation that he seems to agree with for the first time. He does not mention Dharmottara's name, but what he is espousing is obviously Dharmottara's assertion. Instead of doing so, (despite Dharmottara being the inventor of the idea) he says that the interpretation is from the Vādanyāya, another treatise of Dharmakirti which he apparently composed after the PVin which lacks a demonstration of Method [1]. Based on this it appears that the idea first came from Dharmakīrti's text, not Dhamottara's. Or, at least, some of readers may think after reading the above statements that he did not underpin Dharmottara's views, which previous bKa' gdams masters strictly criticized, but simply those of Dharmakirti. 


\section{Another Interpretation in the sDe bdun rGyan gyi me tog}

The sDe bdun rGyan gyi me tog is not a commentary on the PVin but bCom ldan rig ral's own text dealing with the Buddhist epistemology, so one may hold that it does not belong in this paper. However, what he declares in the text deserves consideration because it seems that he composed it before rNam nges rGyan gyi me tog (cf. van der Kuijp $2003,409)$ and when he did so-even though there are no corresponding comments in the rNam nges rGyan gyi me tog-he might have been aware of the below interpretation.

As I showed before, bCom ldan rig ral did not make clear his understanding of the relationship between Method [1] and [2] in the rNam nges rGyan gyi me tog. In contrast, in the sDe bdun rGyan gyi me tog (pp. 103-104), he explains that Method [1] verifies the pervasion between produced/existent things and impermanence "directly" and that Method [2] is "at the second hand" (shugs la). The reason for the former is that the subject of Method [1] is "produced/existent things," which is the valid reason of the primary inference, i.e., proving the momentariness of sound (śabda), etc. Thus one can certify the pervasion in question by using Method [1] without any additional steps. On the other hand, the subject of Method [2] is "permanent things," which is the opposite of the inferential object (sādhyaviparyaya) in case of the primary inference, and Method [2] verifies the pervasion in a negative way. Thus when verification by Method [2] is done, one should shift the subject in Method [2] into the opposite of the object in the case of the primary inference, and finally one then applies the result of verification (based on Method [2]) into the inference of momentariness.

Whether bCom ldan rig ral changed his interpretation of the relationship of two methods or not is hard to tell. But, at least, he did not agree with the hierarchical relationship in them and rather tried to see both as two independent different types of means.

\section{Concluding Remarks}

In conclusion, I suggest the possibility that bCom ldan rig ral was one of the people who influenced the transference of the interpretation of the two methods for proving momentariness. He supported the idea of Method [1] being an aid to Method [2], although he did not attribute the original idea to Dharmottara (even though it is very 
similar to Dharmattora's assertion), merely introducing Dharmottara's assertion without discussing its pros and cons. Furthermore, he did not understand Method [1] and [2] to be in a hierarchical relationship, unlike bKa' gdams masters. Based on the sDe bdun rGyan gyi me tog, one can say for certain that he thought the two methods were parallel tools for proving on the same one thing.

\section{Abbreviations}

PVin

sDe bdun rgyan gyi me tog

rNam nges rGyan gyi me tog
Dharmakīrti, Pramānaviniścaya; Pramānaviniścaya (Chapters 1 and 2). Ed. Ernst Steinkellner. Sanskrit Texts from the Tibetan Autonomous Region, no. 2 Beijing: China Tibetology Publishing House; Vienna: Austrian Academy of Sciences Press, 2007.

bCom ldan rig pa'i ral gri Dar ma rgyal mtshan, Tshad ma bstan bcos sde bdun rgyan gyi me tog. Ed. rDo rje rgyal po. Beijing: Krung go'i bod kyi shes rig dpe skrun khang, 1991.

bCom ldan rig pa'i ral gri Dar ma rgyal mtshan, Tshad ma rnam par nges pa'i 'grel bshad rgyan gyi me tog. Ed. rDo rje rgyal po. Beijing: Krung go'i bod kyi shes rig dpe skrun khang, 1991.

\section{Bibliography}

Choi Kyeongjin 崔境眞. 2015. "Darumarinchen no svabhāvapratibandha rikai: Honshitsuteki musubitsuki ('brel ba) no teigi o megutte” ダルマリンチェンの svabhāvapratibandha 理解: 本 質的結び付き（'brel ba）の定義をめぐって. Nihon Chibetto Gakkai kaihō 日本西蔵学会々報 60: $29-41$.

—. 2016. "Puramāna vinishuchaya (Ninshikishudan kakuteiron) no setsunametsu ronshō o megutte: Kadamu-ha, Sanpusōin-kei shochūshaku o chūshin ni” 『プラマーナ・ヴィニシュ チャヤ（認識手段確定論）』の刹那滅論証をめぐって: カダム派・サンプ僧院系諸註釈を 中心に. PhD diss., The University of Tokyo.

Sakai, Masamichi. 2011. "Śākyabuddhi and Dharmottara on the Inference of Momentariness Based on the Absence of External Causes of Destruction." In Religion and Logic in Buddhist Philosophical Analysis: Proceedings of the Fourth International Dharmakirti Conference. Vienna, August 23-27, 2005, ed. Helmut Krasser et al., 407-421. Wien: Verlag der Österreichischen Akademie der Wissenschaften.

van der Kuijp, Leonard. 2016. "The Lives of Bu ston Rin chen grub and the Date and Sources of His Chos 'byung, a Chronicle of Buddhism in India and Tibet.” Revue d'Etudes Tibétaines 35: 203-308.

Key words Pramānaviniścaya, bCom ldan rig ral, kṣaṇikatva, bādhakapramāṇa

(Project Research Fellow, International College for Postgraduate Buddhist Studies) 